\title{
Introducing R. William (Bill) Currie as the new Editor-in-Chief of Cell Stress \& Chaperones
}

\section{Lawrence E. Hightower ${ }^{1}$}

Accepted: 1 February 2021 / Published online: 15 February 2021

(C) Cell Stress Society International 2021

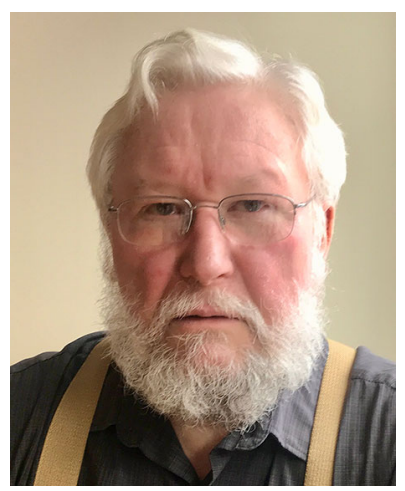

R. William Currie

I retired as Editor-in-Chief on December 31, 2020, after 25 years. Cell Stress \& Chaperones was my cultural baby and I watched it grow as an infant and develop into a child and young adult. But like biological children, journals are unlikely to mature into independent, fully functional adults if the parents hold their child closely for too long. One reason that I can retire comfortably at this moment is that our journal has a very talented board of Senior Editors that includes Bill Currie. Another reason is that our founding Office Manager Helen Neumann, bringing her wealth of knowledge gained from 25 years of experience, is continuing with the Journal.

Bill introduced himself to me at the 1985 Cold Spring Harbor Heat Shock Meeting. I think he was surprised that I knew much of his post-doctoral work with his mentor Fredric P. White. Fred and I had met about 7 years earlier following a string of events sufficiently unique and improbable as to raise the possibility of Divine guidance. Suffice it to say that a mutual academic colleague noticed that we were both studying a small set of proteins for no apparent reason other than

Lawrence E. Hightower

lawrence.hightower@uconn.edu

1 University of Connecticut, Storrs, CT, USA they had unexpectedly and annoyingly appeared in otherwise perfectly reasonable experimental protocols. Our shared colleague was Barry G. Hall who had recently arrived at the University of Connecticut from Memorial University of Newfoundland where he and Fred had become fast friends. I think Barry's motivation probably was to help relieve the frustration of two colleagues he cared about! Now it is well known that these unexpected proteins are the mammalian and avian versions of the Drosophila heat shock proteins (HSP) discovered by Alfred Tissières in 1974 following upon the discovery of the heat shock response by Ferruccio Ritossa in 1962.

Fred and I began working together to determine if our sets of strange proteins were related. Along the way, Fred mentioned that a postdoc named Bill Currie with a Ph.D. in Anatomy from the University of Manitoba had joined his laboratory and would be working on a related project. In 1981, we published our initial work showing that newly synthesized proteins in rat tissue slices incubated in vitro and cultured avian and mammalian cells producing abnormal proteins that had incorporated the arginine analog canavanine were indeed the same or closely related set of proteins. In that same year, Fred contacted me and told me that he and Bill had written a manuscript for Science showing that at least one of these proteins he named P71 was induced by hyperthermic shock in rats and in tissue slices subjected to the trauma of slicing and in vitro incubation. P71 is now known in humans as HSPA1A and as Bill and Fred showed in 1981 (Currie and White 1981), it is induced in response to tissue trauma and as they proposed, this set of cellular stress response proteins has physiologically relevant roles in the responses of humans to trauma as well and to a broad range of environmental stressors in virtually all known organisms. Their article is recognized as a pioneering contribution to the cell stress and chaperones field and their joint work years ago has gained recent attention during the current scramble to understand COVID-19, a disease that targets the vascular endothelium of victims to elicit physiological response of the sort triggered by trauma. 
Bill joined the Department of Anatomy (now Medical Neuroscience) at Dalhousie University in 1982 and retired at the end of 2016. During his career, Bill received numerous awards. A sampling includes the Dalhousie Medical Research Foundation's Max Forman Senior Research Prize for dedication and commitment to excellence in research, a Canadian Institutes of Health Research/Centre National de la Recherche Scientifique (CIHR/CNRS) International Scientific Exchange award, Université Claude Bernard Lyon-1, France, with André-Patrick Arrigo, awards from the Province of Québec with longtime colleague Robert M. Tanguay, and Visiting Scientist, Institute of Occupational Medicine, Tongji Medical College, Huazhong University of Science and Technology, Wuhan, China, with Tangchun Wu. Bill is recognized internationally for pioneering studies showing induced expression of HSP in live animals, and that HSP improve post-ischemic contractile recovery of hearts and suppress inflammation. He currently maintains a post-retirement appointment at Dalhousie University.

Bill has delivered more than 40 invited international conference presentations and has 80 publications with 5100 citations. In 1988, Bill and his coworkers provided evidence that hyperthermia treatment at temperatures that induce HSP has therapeutic potential for salvaging ischemic myocardium during reperfusion. They showed that this involves a mechanism that increases levels of myocardial catalase (Currie et al. 1988). I had the pleasure of participating in the $\mathrm{PhD}$ thesis defense of Christophe Plumier in Halifax. Part of his research involved the use of transgenic mice that expressed constitutively human HSPA1A. The mice were given an operation that permanently occluded their middle cerebral artery. Only in transgenic mice did hippocampal pyramidal neurons show normal morphology. Constitutive expression of HSPA1A appeared to reduce damage following cerebral artery occlusion (Plumier et al. 1997). In 2000, Bill and his coworkers published an article that showed the induction of a cell typespecific expression of rat constitutive and inducible HSP70 in blood vessels but not myocytes or intrinsic cardiac neurons. This observation further suggested that blood vessels play a primary role in myocardial protection (Leger et al. 2000). In another paper in Cell Stress \& Chaperones, Bill and his colleagues demonstrated that heat shock treatment of rats induces high levels of HSP70 and the small HSP27, a treatment that protects against angiotensin II-induced hypertension and inflammation. They proposed that these protections may be related to the interaction of HSP and the NF-kB pathway (Chen et al. 2004).

Bill was a founding member of the Cell Stress Society International in 1995. He was elected a Fellow (2016) for his work on the Editorial Board of Cell Stress \& Chaperones as a reviewing editor and subsequently he was elected a Senior Fellow (2019) for his excellent contributions as a Senior Editor starting in 2014. Bill helped to develop the publishing philosophy of our Journal.

His sense of scientific integrity and his adherence to international standards of publishing ethics helped to set a high standard for reviewing and editing. At Cell Stress \& Chaperones, authors from all over the globe are treated fairly and equitably. Under Bill's leadership, our goal to make each manuscript the best will continue. Dear readers, I think you will agree that we have made a wise choice for the new Editorin-Chief!

With warm regards,

Larry Hightower

\section{References}

Chen Y, Ross BM, William Currie R (2004) Heat shock treatment protects against angiotensin II-induced hypertension and inflammation in aorta. Cell Stress Chaperones 9(1):99-107

Currie RW, White FP (1981) Trauma-induced protein in rat tissues: a physiological role for a heat shock protein? Science 214(4516): $72-73$

Currie RW, Karmazyn M, Kloc M, Mailer K (1988) Heat-shock response is associated with enhanced postischemic ventricular recovery. Circ Res 63(3):543-549

Leger JP, Smith FM, Currie RW (2000) Confocal microscopic localization of constitutive and heat shock-induced proteins HSP70 and HSP27 in the rat heart. Circulation 102(14):1703-1709

Plumier J-C et al (1997) Transgenic mice expressing the human inducible Hsp70 have hippocampal neurons resistant to ischemic injury. Cell Stress Chaperones 2(3):162-167

Publisher's note Springer Nature remains neutral with regard to jurisdictional claims in published maps and institutional affiliations. 